\title{
Detecting Hepatitis B and C by Combined Public Health and Primary Care Birth Cohort Testing
}

Jeanne Heil, MSc $\mathrm{c}^{1,2}$

Cbristian J. P. A. Hoebe, Prof ${ }^{1,2}$

Jochen W. L. Cals, $P b D^{3}$

Henriëtte L. G. ter Waarbeek, MD $D^{1,2}$

Inge H. M. van Loo, PbD ${ }^{2}$

Nicole H. T. M. Dukers-Muijrers, $P b D^{1,2}$

'Department of Sexual Health, Infectious Diseases and Environmental Health, Public Health Service (GGD) South Limburg, Heerlen, The Netherlands

${ }^{2}$ Department of Medical Microbiology, Care and Public Health Research Institute (CAPHRI), Maastricht University Medical Centre, Maastricht, The Netherlands

${ }^{3}$ Department of Family Medicine, Care and Public Health Research Institute (CAPHRI), Maastricht University, Maastricht, The Netherlands

Conflicts of interest: authors report none.

\section{CORRESPONDING AUTHOR}

Jeanne Heil, MSc

Department of Sexual Health, Infectious

Diseases and Environmental Health

Public Health Service (GGD)

South Limburg, PO Box 336400 AA

Heerlen, The Netherlands

Jeanne.Heil@ggdzl.nl

\begin{abstract}
PURPOSE Both chronic hepatitis C (HCV) and B virus (HBV) infections are generally asymptomatic, and many remain undetected or are diagnosed at a late stage. Studies that evaluate best practice hepatitis testing strategies are needed to better detect this hidden population.
\end{abstract}

METHODS In this prospective cohort study, we aimed to determine the diagnostic yield (test uptake and rate of positive test results) of a combined public health and primary care birth cohort testing strategy in detecting hidden cases of HCV and HBV infections. We invited all patients aged between 40 and 70 years $(n=6,743)$ registered with 11 family practices serving 2 higher prevalence areas, or hotspots (ie, estimated HCV prevalence of 1\%; national estimated prevalence is $0.1-0.4 \%)$, in the south of the Netherlands.

RESULTS Test uptake was $50.9 \%$ ( $n=3,434$ patients). No active or chronic HCV infection was detected: $0.00 \%(95 \% \mathrm{Cl}, 0.00 \%-0.11 \%)$. Positive test rates were $0.20 \%$ (95\% Cl, 0.08\%-0.42\%) for anti-HCV $(n=7), 0.26 \%(95 \% \mathrm{Cl}, 0.12 \%-$ $0.50 \%)$ for hepatitis B surface antigen $(n=9)$, and $4.14 \%(95 \% \mathrm{Cl}, 3.49 \%$ $4.86 \%)$ for antihepatitis B core $(n=142)$.

CONCLUSIONS This best practice testing strategy was effective in achieving a high test uptake. It completely failed, however, to detect hidden chronic HCV infections and is not recommended for countries with a low prevalence of the disease.

Ann Fam Med 2018;16:21-27. https://doi.org/10.1370/afm.2166.

\section{INTRODUCTION}

C hronic hepatitis $\mathrm{C}$ virus (HCV) and B virus (HBV) infections, major causes of chronic liver disease worldwide, are generally asymptomatic, and many infections remain hidden to care or are diagnosed at a late stage..$^{1-5}$ Because treatment for HCV infection has greatly improved, identification of $\mathrm{HCV}$-infected individuals has become even more imperative. ${ }^{6}$ Yet, strategies to detect cases of HCV infection hidden in the general population have been disappointing. Currently, it is universally recommended to offer testing to individuals who are part of a population with a high prevalence of HCV or HBV infection or who have a history of risk exposure or behavior. ${ }^{7-10}$ Risk groups include injection drug users, recipients of infected blood products, children of HCVpositive mothers, and human immunodeficiency virus (HIV)-infected persons. ${ }^{11-14}$ Past drug users or recipients of blood transfusions will remain hidden, however, as they may not remember or report these behaviors. ${ }^{15}$

To capture all persons who have HCV infection, prospective studies are needed that evaluate the diagnostic yield of HCV testing strategies not based on exposure risk factors. ${ }^{16}$ Birth cohort screening, as currently recommended in the United States (HCV prevalence of 2.0\%), has also been suggested for European countries. ${ }^{9}, 17,18$ In simulation models, onetime HCV testing in the 1945-1965 birth cohort with subsequent treatment was likely cost-effective in the United States. ${ }^{19}$ Yet again, primary care clinicians faced with the increasing societal need to screen for HCV 
infections encounter practical challenges in diagnosis and linking patients to appropriate care..$^{20}$ There is also debate on whether expanded screening will lead to net clinical benefit or harm, given the lack of evidence regarding screening efficacy. ${ }^{21}$ Whether the birth cohort approach is a useful strategy for countries with low estimated HCV prevalence, such as the United Kingdom (0.7\%) and the Netherlands (0.1-0.4\%), needs to be demonstrated in practice..$^{15,22-25}$

In countries with a low prevalence of HCV infection, a high test uptake is crucial to increase the number of diagnoses and thereby the diagnostic yield of a birth cohort approach. According to a meta-analysis, targeted practitioner-based studies are most effective in increasing test uptake and cases detected. ${ }^{26}$ Diagnostic yield could be further optimized by focusing on areas of higher prevalence. Based on spatialepidemiological analyses of laboratory data, the estimated prevalence of $\mathrm{HCV}$ infection in the south of the Netherlands is $0.5 \%$, and HCV infections are found to cluster in urban areas, with a prevalence of up to $1 \% .^{27,28}$ These so-called hotspots are postal codes where there is a statistically significant elevated risk of diagnosed $\mathrm{HCV}$ infection (relative risk $>4$ ). In addition, an estimated $66 \%$ of $\mathrm{HCV}$-infected persons are estimated to be untested and thus hidden to care. ${ }^{27}$

We developed a best practice approach by combining public health and primary care in a birth cohort testing strategy. We applied this approach in 2 identified Dutch hotspots to detect cases of HCV and HBV infection that are hidden in the general population. Our current study describes the development of this strategy and an evaluation of its diagnostic yield to provide insights on possible implementation in lowprevalence countries.

\section{METHODS}

\section{Testing Strategy Development}

The strategy was developed and implemented in a collaboration between public health and primary care.

All family physicians located in the hotspots were approached by a peer family physician. Family physicians agreeing to take part personally invited their eligible patients by means of a letter, which was developed by a multidisciplinary team of family physicians, behavioral scientists, epidemiologists, and language ambassadors. Testing was advertised in local newspapers and through waiting room posters.

The regional public health service (PHS) facilitated the practical organization of the testing by distributing the letters of invitation and reminders, arranging the testing location, and planning and collecting measurements. They organized 3 testing days with different time slots (September 2014 to April 2015) at 2 local community centers. Alternatively, patients could be tested at their family practice, the PHS clinic, at home, or at the hospital. Tests were free of charge. Patients not tested received a reminder letter for testing 1 week later. Both participants tested and patients who declined to be tested were invited to complete a short questionnaire. Participants provided written informed consent, and the study was approved by the university medical ethics committee (MUMC; $14-4-042$ ).

\section{Testing Strategy Implementation}

Two hotspots were targeted because of their highest regional estimated prevalence of HCV infection. ${ }^{28}$ The family practices agreeing to participate invited patients aged between 40 and 70 years for a HCV and HBV test. Blood samples were transported within 3 hours of collection to the laboratory. Initial screening included anti-HCV and antihepatitis B core (antiHBc) (Anti-HCV II and Anti-HBc, Roche Diagnostics). When a screening test was positive, subsequent tests included the following: HCV ribonucleic acid (RNA) (COBAS, Ampliprep/COBAS, Taqman HCV Quantitative Test, version 2.0, Roche Diagnostics) and/or immunoblot (Mikrogen), a hepatitis B surface antigen ( $\mathrm{HBsAg}$ ) test, and an antihepatitis B surface (anti-HBs) test (HBsAg II and Anti-HBs, Roche Diagnostics) (see Figure 1).

In HBsAg-positive samples additional tests were performed, including hepatitis $\mathrm{B}$ e antigen $(\mathrm{HBeAg})$, anti-HBeAg, anti-HBc immunoglobulin M (IgM), HBV deoxyribonucleic acid (DNA), and alanine aminotransferase (ALT) (HBeAg, Anti-HBe, Anti-HBc IgM, COBAS, Ampliprep/COBAS, Taqman HBV Test, ALT, Roche Diagnostics). In solitary anti-HBc-positive samples, $\mathrm{HBeAg}$, anti-HBeAg, and HBV DNA tests were performed (Roche Diagnostics). Samples with weak positive anti-HBc, HBsAg, or anti-HCV test results (between 1 and $2 x$ cutoff value) were confirmed with a second screening test (BioMerieux).

Within 3 weeks after testing, the family physician informed the patient about the test results. In the case of an active HCV or HBV infection, the family physician referred the patient to a gastroenterologist at the academic hospital, who ensured routine care and treatment when needed. For those with $\mathrm{HBsAg}$-positive tests, follow-up testing was conducted after 6 months to discriminate between acute and chronic infections. The regional public health service performed contact tracing for all cases of active infections and offered hepatitis A virus (HAV) vaccination for the patient and HBV vaccination for close contacts to prevent further spread. 


\section{Figure 1. The laboratory testing algorithm used for identifying hepatitis C virus and hepatitis $B$ virus} infection.

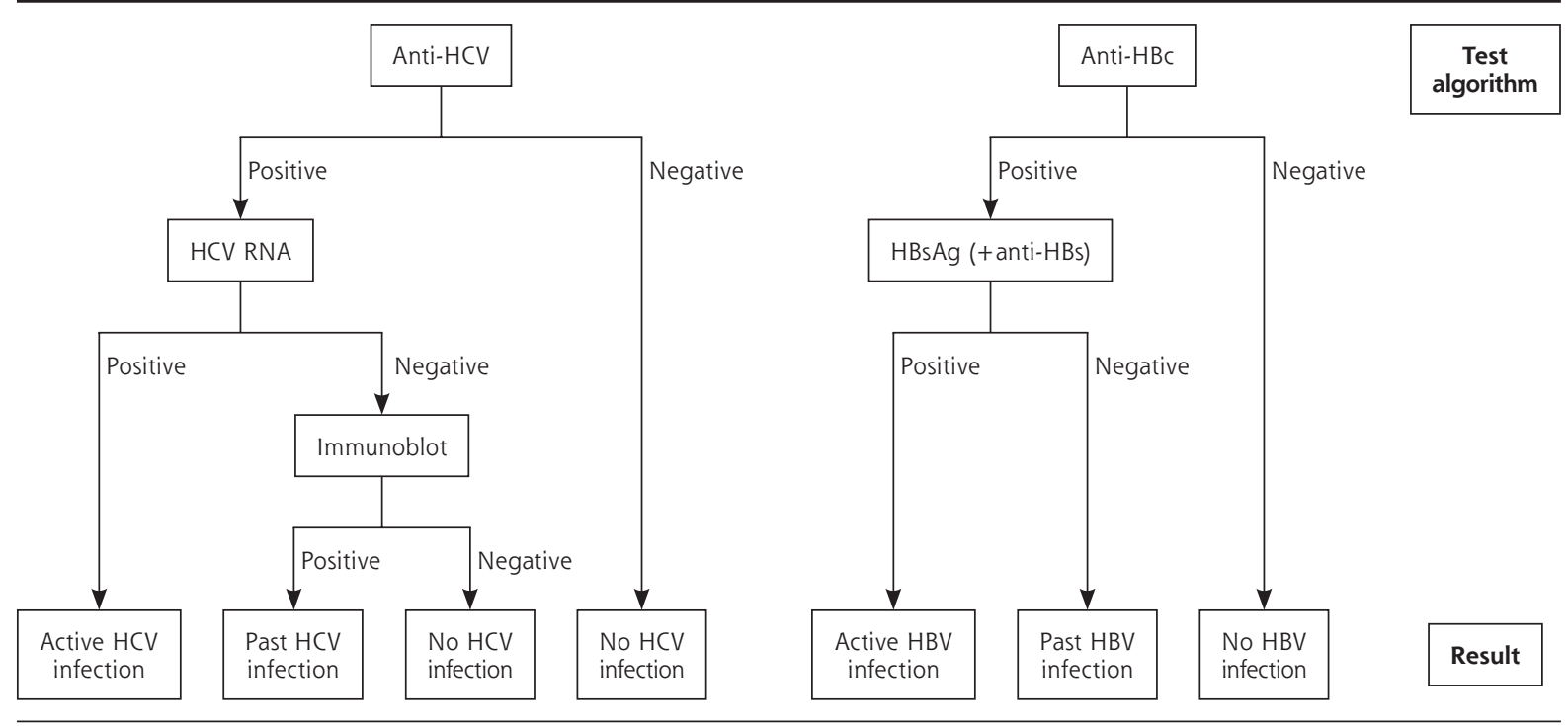

$\mathrm{HBV}=$ hepatitis $\mathrm{B}$ virus, $\mathrm{HBC}=$ hepatitis $\mathrm{B}$ core; $\mathrm{HBs}=$ hepatitis $\mathrm{B}$ surface; $\mathrm{HCV}=$ hepatitis $\mathrm{C}$ virus; $\mathrm{RNA}=$ ribonucleic acid

\section{Data Collection}

For this prospective cohort study, coded data on sex, age, postal code, and referral to a gastroenterologist were retrieved from the family physician registry, and test results were obtained from the laboratory. Questionnaires included the following determinants: country of birth (participant, mother, and father), educational level, working situation, living situation, and previous HCV or HBV infection. Education was categorized into low (no, primary, and lower vocational education), intermediate (intermediate vocational, higher secondary, and vocational education), and high (higher professional education and university). The participants questionnaire also included HCV exposure risk factors (ie, surgery abroad, blood transfusion or organ transplant before 1992, diagnosis of HIV infection, or a history of intravenous drug use), as well as reasons for participating. The questionnaire for those who declined testing included reasons for not participating. The PHS data included the number of close contacts of all active infections and the number of vaccinations of both the patients (for HAV) and their contacts (for HBV).

\section{Statistical Analysis}

The diagnostic yield of the testing strategy was evaluated in terms of achieved rates of test uptake and positive test results. A priori, we expected a test uptake of $40 \%$ based on international targeted-testing studies and Dutch studies using personal letter invitations. ${ }^{29-34}$ A positive anti-HCV test rate higher than the estimated Dutch prevalence of $0.1 \%-0.4 \%$ would be con- sidered promising to explore further assessment and implementation of the testing strategy. ${ }^{23-25}$ Test uptake and rates of positive test results were calculated among the patients invited and participants, and associated determinants were assessed using multivariate logistic regression analyses; determinants included hotspot, sex, age, educational level, and hepatitis exposure risk factors as non-Western migrant, surgery abroad, blood transfusion or organ transplant before 1992, HIV positive, or a history of intravenous drug use. Analyses were performed using SPSS 21.0 (IBM Inc).

\section{RESULTS}

All 11 family practices in the targeted areas agreed to take part, and 6,743 patients (excluding failed delivery) between the ages of 40 and 70 years were sent invitations to participate in the study.

\section{Diagnostic Yield: Test Uptake}

In total, 3,434 of the 6,743 patients invited were tested for HCV and HBV infection. The test uptake was $50.9 \%$ (95\% CI, 49.7\%-52.1\%) (Figure 2). Of those participating, $54.3 \%$ were women, the mean age was 57.3 years $(\mathrm{SD}=8.1$ years), $47.4 \%$ had a low education level, and $17.2 \%$ had at least 1 hepatitis exposure risk factor.

\section{Diagnostic Yield: Rate of Positive Test Results}

No active HCV infection was diagnosed (95\% CI, $0.00 \%-0.11 \%)$. The rate of positive tests for anti$\mathrm{HCV}$, confirmed by immunoblot, was $0.20 \%$ (95\% CI, 


\section{Figure 2. Flow diagram of the birth cohort testing for hepatitis C virus and hepatitis B virus infection.}

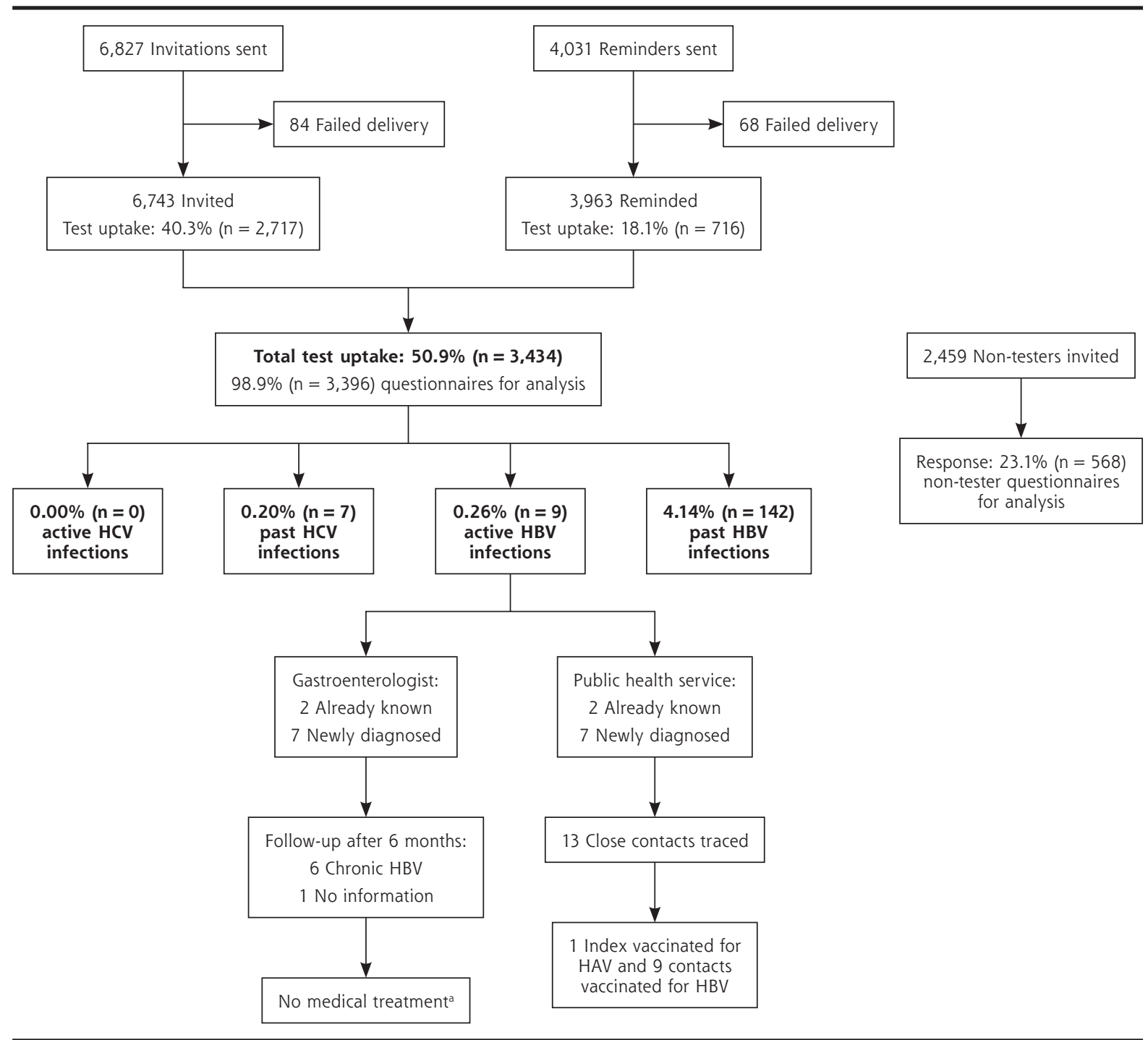

$\mathrm{ALT}=$ alanine aminotransferase; DNA = deoxyribonucleic acid; HAV = hepatitis $A$ virus; $H B V=$ hepatitis $B$ virus, $H C V=$ hepatitis $C$ virus.

a Medical treatment is not indicated in active HBV infections. In chronic HBV infections, treatment is indicated if the HBV DNA level is $>1.0 \times 10^{5}$ copies/mL combined with an elevated ALT level or major liver fibrosis.

$0.08 \%-0.42 \%)(\mathrm{n}=7)$, for HBsAg was $0.26 \%(95 \%$ CI, $0.12 \%-0.50 \%)(n=9)$, and for anti-HBc was $4.14 \%$ (95\% CI, 3.49\%-4.86\%) $(\mathrm{n}=142)$ (Figure 2). The numbers screened needed to detect 1 case of a positive anti-HCV, HBsAg, or anti-HBc test were 491, 382, and 24 , respectively. Seventy-one percent $(n=5)$ of the anti$\mathrm{HCV}$ positive tests results, $22 \%(\mathrm{n}=2)$ of the $\mathrm{HBsAg}$ positive tests results, and $9 \%(n=13)$ of the anti-HBc positive findings were associated with a history of $\mathrm{HCV}$ or HBV infection. All $9 \mathrm{HBsAg-positive} \mathrm{partici-}$ pants had negative $\mathrm{HBeAg}$ and $\operatorname{IgM}$ anti-HBc findings and had an ALT level of $<45 \mathrm{U} / \mathrm{L}$. All were referred to a gastroenterologist. Seven of 9 active HBV infections were undiagnosed and were further assessed by the hospital and the PHS. Six participants were chronically infected with HBV, ie, their $\mathrm{HBsAg}$ tests remained positive after 6 months. Treatment was not indicated for any of these patients according to their serum ALT levels, HBV DNA load, or signs of liver fibrosis and status on hepatocellular carcinoma. The PHS traced 13 close contacts of HBsAg-positive participants, and HBV vaccination was needed and given in 9 (Figure 2).

\section{Determinants of Test Uptake}

No differences in test uptake between the 2 hotspots were observed. Test uptake was higher among women 
(54.4\%) and older participants, with an uptake of $61.2 \%$ among those aged 60 to 70 years (Table 1). Participants had a lower educational level than those not tested (Supplemental Appendix 1, available at http:// www.annfammed.org/content/16/1/21/suppl/ $\mathrm{DC} 1 /$ ). The reported reasons to get tested were because of the invitation by the family physician $(62 \%, \mathrm{n}=2,120)$ or to rule out hepatitis $(33 \%, \mathrm{n}=1,132)$. Patients declining to be tested reported reasons for not testing as a low risk perception $(33 \%, \mathrm{n}=133)$, practical reasons $(24 \%, \mathrm{n}=94)$, and being vaccinated or tested in the past $(14 \%, \mathrm{n}=55)$. Reasons based on stigma or fear were rare $(3 \%, \mathrm{n}=12)$.

\section{Determinants of Positive Test Results}

Rates of positive test results were higher in those individuals with an exposure risk factor for anti-HCV, HBsAg, and anti-HBc $(0.68 \%, 1.19 \%$, and $11.02 \%$, respectively) than in those without such a risk factor $(0.11 \%, 0.07 \%$, and $2.71 \%$, respectively). Logistic regression analyses assessing additional determinants for past HBV infection found the highest positive anti-HBc test rate among non-Western migrants $(27.6 \%, \mathrm{n}=48$ of 174$)$ $(\mathrm{OR}$ [odds ratio] $=16.1 ; 95 \% \mathrm{CI}, 10.4-24.9), \mathrm{HIV}$-positive patients $(22.2 \%, \mathrm{n}=2$ of 9$)(\mathrm{OR}=6.7 ; 95 \% \mathrm{CI}, 1.4-33.3)$, and individuals with a history of intravenous drug use $(28.6 \%, \mathrm{n}=2$ of 7$)(\mathrm{OR}=8.2 ; 95 \% \mathrm{CI}, 1.5-43.2)$, when adjusted for a higher prevalence area, sex, and age.

\section{DISCUSSION}

A combined public health and primary care birth cohort testing strategy to detect hidden $\mathrm{HCV}$ and HBV infections in higher prevalence areas in the Netherlands had a limited diagnostic yield. This best practice approach was able to gain a higher than expected test uptake of $51 \%$, but it completely failed to detect hidden $\mathrm{HCV}$ infections

The current test uptake of 51\% was higher compared with international studies targeted to risk factors (10\% to $49 \%)$ and other Dutch studies with a personal invitation (18\% to $42 \%) .{ }^{29-36}$ The family physicians' personal invitation appeared key for achieving this high uptake, as confirmed by the reported main reason to get tested. Test uptake in specific settings, such as the emergency department, may be even higher (up to $65 \%),{ }^{37}$ as here tests can be offered and performed within the routine diagnostic work-up.

The main result is that no active $\mathrm{HCV}$ infections were detected. A higher prevalence was expected based on previous estimations in these hotspots $(0.5 \%$ to
Table 1. Sociodemographic Determinants of Test Uptake of the Public Health and Primary Care Birth Cohort Testing Strategy

\begin{tabular}{|c|c|c|c|}
\hline Determinant & $\begin{array}{c}\text { Test Uptake } \\
\% \text { (No.) }\end{array}$ & $\begin{array}{l}\text { Not Tested } \\
\% \text { (No.) }\end{array}$ & OR $(95 \% \mathrm{Cl})^{\mathrm{a}}$ \\
\hline \multicolumn{4}{|l|}{ Higher prevalence area } \\
\hline Hotspot A $(n=2,891)$ & $50.2(1,450)$ & $49.8(1,441)$ & $1.05(0.95-1.16)$ \\
\hline Hotspot B $(n=3,949)$ & $50.2(1,984)$ & $49.8(1,965)$ & 1 [Reference] \\
\hline \multicolumn{4}{|l|}{ Sex } \\
\hline Male $(n=3,417)$ & $46.0(1,571)$ & $54.0(1,846)$ & 1 [Reference] $^{\mathrm{b}}$ \\
\hline Female $(n=3,423)$ & $54.4(1,863)$ & $45.6(1,560)$ & $1.41(1.28-1.55)$ \\
\hline \multicolumn{4}{|l|}{ Age, y } \\
\hline $40-49^{c}(n=1,891)$ & $35.0(662)$ & $65.0(1,229)$ & 1 [Reference] $^{\mathrm{b}}$ \\
\hline $50-59(n=2,531)$ & $51.0(1,292)$ & $49.0(1,239)$ & $1.93(1.71-2.18)$ \\
\hline $60-70^{d}(n=2,418)$ & $61.2(1,480)$ & 38.8 (938) & $2.95(2.60-3.34)$ \\
\hline \multicolumn{4}{|l|}{$\mathrm{OR}=$ odds ratio. } \\
\hline $\begin{array}{l}\text { a } \text { Adjusted for higher prevalen } \\
\text { b } P \leq .001 . \\
\text { ' Includes } 2 \text { aged }<40 \text { years. } \\
{ }^{d} \text { Includes } 9 \text { aged }>70 \text { years. }\end{array}$ & area, sex, and ag & & \\
\hline
\end{tabular}

$1 \%)_{1}^{27,28}$ or other Dutch studies focusing on risk groups $(0.3 \%$ to $4.8 \%),{ }^{32,34,38,39}$ and on (inter)national estimations that a substantial population is untested. ${ }^{2-5}$ Estimates of the hidden HCV-infected population, however, are largely derived from mathematical models ( $43 \%$ to $72 \%)$. The number of hidden cases of chronic HCV infection seems to be overestimated compared with a real-life setting. The detected rate of tests positive for anti-HCV is $0.2 \%$ and for $\mathrm{HBsAg}$ is $0.3 \%$, which is comparable to the general prevalence in the Netherlands $(0.1 \%$ to $0.4 \%){ }^{23-25,40,41}$ The rate of positive anti-HBc test results (4.1\%) was higher compared with the Dutch estimated prevalence of $2.1 \%{ }^{41}$ Yet, this finding has no implications for patient care. Higher positive rates and lower numbers needed to screen to detect 1 case have been found in birth cohort studies in higher prevalence settings and countries, such as the United States. ${ }^{15,26,37,42}$

Detected positive rates were higher in those with a hepatitis exposure risk factor, a finding in line with studies targeting risk factors. ${ }^{15,26}$ Using a risk group instead of the birth cohort, however, would have missed $22 \%$ to $54 \%$ of all positive cases in this study (3 of 7 anti-HCV-positive cases, 2 of $9 \mathrm{HBsAg-positive} \mathrm{cases,}$ and 77 of 142 anti-HBc-positive cases). ${ }^{7 \cdot 10}$ For chronic HBV infections specifically, several studies state that systematic screening among migrants is likely to be cost-effective or at least increases its efficiency. ${ }^{43,44}$ This is in line with family physician guidelines in the United Kingdom and the Netherlands, as well as the recommendations of the Dutch Health Council to target HBV testing, such as to non-Western migrants. ${ }^{7,45}$

Our study is the first in Europe to develop a public health and primary care birth cohort testing strategy 
to detect hidden cases of HCV and HBV infection in identified hotspots and evaluate its diagnostic yield. Our study has some limitations. First, selection bias cannot be ruled out, as many $\mathrm{HCV}$-infected patients are at a disadvantage in terms of health literacy. ${ }^{46}$ In the Netherlands, health insurance is obligatory, and family physicians function as a gatekeeper to specialist care, but some individuals might have been less likely to get tested. Nevertheless, those who were tested and those who were not did not differ in assessed characteristics, such as working or living situation, or migrant status. Moreover, study participants had an even lower educational level compared with those declining to be tested, and national estimates support that we were able to reach intravenous drug users. ${ }^{47,48}$

Second, behavioral data are self-reported and could be influenced by recall bias and social desirability bias. Third, questions on sexual exposure risk were not included, based on feasible questionnaire length. Fourth, the data from those not tested might be less generalizable to the general population because of low response (23\%). Fifth, hotspots were determined based on laboratory data of the tested population. We assumed that the hidden, untested population follows the same geographical pattern. Finally, as no active $\mathrm{HCV}$ infections and only small numbers of past HCV and active HBV infections were detected, we were able to assess more detailed determinants only for past HBV infections.

Because no active $\mathrm{HCV}$ infections were found in the identified hotspots, it is likely that the strategy taken would not be effective in other areas of the Netherlands and other low-prevalence countries. Our testing strategy can be applied to detecting HCV and HBV infections, as well as other infectious diseases, in high-endemic countries, such as the United States. If the test is not offered for free, however, a lack of health insurance could be a limiting factor in the United States. Considering the different health care system in the United States, the test uptake of a similar testing strategy might be lower in certain groups at risk, such as intravenous drug users or patients co-infected with HIV. Lessons learned can also be applied to future studies aimed at retracing patients previously diagnosed with HCV and HBV. The success factor of our high test uptake is the combination of a personal invitation accompanied by reminders, and the cooperation between public health care and primary care. Moreover, our findings informed the Dutch Health Council in their recommendation not to screen the general population for HCV and HBV infection. ${ }^{45}$

To read or post commentaries in response to this article, see it online at http://www.AnnFamMed.org/content/16/1/21.
Key words: hepatitis B virus; hepatitis C virus; birth cohort screening; hotspots; hidden population; primary health care; public health

Submitted February 13, 2017; submitted, revised, June 23, 2017; accepted July 12, 2017.

Funding support: This work was supported by the National Institute for Public Health and the Environment [0037-2014] and AbbVie Inc. [A14-989].

Disclaimer: None of the sponsors had any role in the study design or conduct of the study; in the collection, management, analysis, or interpretation of the data; the preparation of the manuscript; or in the decision to submit the manuscript for publication.

Previous presentations: 26th ECCMID Congress, the European Congress of Clinical Microbiology and Infectious Diseases, April 9-12, 2016 (O206), Amsterdam, the Netherlands; Nationale Hepatitis Dag 2016, November 1, 2016, Amsterdam, the Netherlands; ESCAIDE 2017, European Scientific Conference on Applied Infectious Disease Epidemiology، November 6-8, 2017, Stockholm, Sweden.

Acknowledgments: We wish to thank Peter HA Jacobs (GGD LimburgNoord, Venlo), Arjan ER Bos (Open University, Heerlen), Boris Kauhl, Gerjo Kok, Karlijn Massar, and Stefan LK Gruijters (Maastricht University Medical Centre, Maastricht), all participating family practices, community nurses, community centers, language ambassadors (Arcus College, Heerlen), laboratory analysts (laboratory of Medical Microbiology, Maastricht), medical specialists (Maastricht University Medical Centre, Maastricht), and the staff of the regional public health service (GGD Zuid-Limburg), for their advice, cooperation, and contribution to the design of this study.

Supplemental materials: Available at http://www.AnnFamMed. org/content/16/1/21/suppl/DC1/.

\section{References}

1. Stanaway JD, Flaxman AD, Naghavi M, et al. The global burden of viral hepatitis from 1990 to 2013: findings from the Global Burden of Disease Study 2013. Lancet. 2016;388(10049):1081-1088.

2. Spradling PR, Rupp L, Moorman AC, et al; Chronic Hepatitis Cohort Study Investigators. Hepatitis B and C virus infection among 1.2 million persons with access to care: factors associated with testing and infection prevalence. Clin Infect Dis. 2012;55(8):1047-1055.

3. Hagan H, Campbell J, Thiede H, et al. Self-reported hepatitis C virus antibody status and risk behavior in young injectors. Public Health Rep. 2006;121(6):710-719.

4. Brouard C, Le Strat Y, Larsen C, Jauffret-Roustide M, Lot F, Pillonel $J$. The undiagnosed chronically-infected HCV population in France. Implications for expanded testing recommendations in 2014. PLoS One. 2015;10(5):e0126920.

5. Denniston MM, Klevens RM, McQuillan GM, Jiles RB. Awareness of infection, knowledge of hepatitis $C$, and medical follow-up among individuals testing positive for hepatitis C: National Health and Nutrition Examination Survey 2001-2008. Hepatology. 2012;55(6): 1652-1661.

6. Tran TT. A review of standard and newer treatment strategies in hepatitis C. Am J Manag Care. 2012;18(14)(Suppl):S340-S349.

7. National Institute for Health and Care Excellence (NICE). Public health guideline 43: Hepatitis B and C testing: people at risk of infection. https://www.nice.org.uk/guidance/ph43. Published Dec 2012. Updated Mar 2013. Accessed May 9, 2016.

8. NHG. NHG-Standaard Virushepatitis en andere leveraandoeningen (derde herziening). Huisarts Wet. 2016. https://www.nhg.org/ standaarden/volledig/nhg-standaard-virushepatitis-en-andereleveraandoeningen. 
9. Smith BD, Morgan RL, Beckett GA, et al; Centers for Disease Control and Prevention. Recommendations for the identification of chronic hepatitis C virus infection among persons born during 1945-1965. MMWR Recomm Rep. 2012;61(RR-4):1-32.

10. Guidelines for the screening, care and treatment of persons with chronic hepatitis C infection. Geneva, Switzerland: World Health Organization; 2016.

11. Nelson PK, Mathers BM, Cowie B, et al. Global epidemiology of hepatitis $B$ and hepatitis $C$ in people who inject drugs: results of systematic reviews. Lancet. 2011;378(9791):571-583.

12. Shepard CW, Finelli L, Alter MJ. Global epidemiology of hepatitis C virus infection. Lancet Infect Dis. 2005;5(9):558-567.

13. Benova L, Mohamoud YA, Calvert C, Abu-Raddad LJ. Vertical transmission of hepatitis $C$ virus: systematic review and meta-analysis. Clin Infect Dis. 2014;59(6):765-773.

14. Taylor LE, Swan T, Mayer KH. HIV coinfection with hepatitis C virus: evolving epidemiology and treatment paradigms. Clin Infect Dis. 2012;55(Suppl 1):S33-S42.

15. Zuure FR, Urbanus AT, Langendam MW, et al. Outcomes of hepatitis $C$ screening programs targeted at risk groups hidden in the general population: a systematic review. BMC Public Health. 2014;14:66.

16. Chou R, Cottrell EB, Wasson N, Rahman B, Guise JM. Screening for hepatitis $C$ virus infection in adults: a systematic review to update the 2004 U.S. Preventive Services Task Force Recommendation. Ann Intern Med. 2013;159(5):349-357.

17. Moyer VA, Force USPST; U.S. Preventive Services Task Force. Screening for hepatitis $C$ virus infection in adults: U.S. Preventive Services Task Force recommendation statement. Ann Intern Med. 2013;159(5):349-357.

18. Alfaleh FZ, Nugrahini N, Matičič M, et al. Strategies to manage hepatitis C virus infection disease burden - volume 3. J Viral Hepat. 2015;22(Suppl 4):42-65.

19. McEwan P, Ward T, Yuan Y, Kim R, L'italien G. The impact of timing and prioritization on the cost-effectiveness of birth cohort testing and treatment for hepatitis C virus in the United States. Hepatology. 2013;58(1):54-64.

20. Lebovics E, Torres R, Porter LK. Primary care perspectives on hepatitis $C$ virus screening, diagnosis and linking patients to appropriate care. Am J Med. 2017;130(2):S1-S2.

21. Koretz RL, Lin KW, loannidis JP, Lenzer J. Is widespread screening for hepatitis C justified? BMJ. 2015;350:g7809.

22. Harris RJ, Ramsay M, Hope VD, et al. Hepatitis C prevalence in England remains low and varies by ethnicity: an updated evidence synthesis. Eur J Public Health. 2012;22(2):187-192.

23. Kok A, Zuure FR, Weegink CJ, Coutinho RA, Prins M. Hepatitis C in Nederland: schaarse gegevens over actuele prevalentie en de noodzaak van epidemiologisch onderzoek en innovatieve opsporingsmethoden. Ned Tijdschr Geneeskd. 2007;151(43):2367-2371.

24. Slavenburg S, Verduyn-Lunel FM, Hermsen JT, Melchers WJ, te Morsche RH, Drenth JP. Prevalence of hepatitis $\mathrm{C}$ in the general population in the Netherlands. Neth J Med. 2008;66(1):13-17.

25. Vriend HJ, Op de Coul EL, van de Laar TJ, Urbanus AT, van der Klis FR, Boot HJ. Hepatitis C virus seroprevalence in the Netherlands. Eur J Public Health. 2012;22(6):819-821.

26. Aspinall EJ, Doyle JS, Corson S, et al. Targeted hepatitis C antibody testing interventions: a systematic review and meta-analysis. Eur J Epidemiol. 2015;30(2):115-129.

27. Vermeiren AP, Dukers-Muijrers NH, van Loo IH, et al. Identification of hidden key hepatitis C populations: an evaluation of screening practices using mixed epidemiological methods. PLoS One. 2012; 7(12):e51194.

28. Kauhl B, Heil J, Hoebe CJ, Schweikart J, Krafft T, Dukers-Muijrers $\mathrm{NH}$. The spatial distribution of hepatitis C virus infections and associated determinants - an application of a geographically weighted Poisson regression for evidence-based screening interventions in hotspots. PLoS One. 2015;10(9):e0135656.
29. Reilley B, Leston J, Hariri S, et al. Birth Cohort Testing for Hepatitis C Virus - Indian Health Service 2012-2015. MMWR Morb Mortal Wkly Rep. 2016;65(18):467-469.

30. Cullen W, Stanley J, Langton D, Kelly Y, Staines A, Bury G. Hepatitis $C$ infection among injecting drug users in general practice: a cluster randomised controlled trial of clinical guidelines' implementation. Br J Gen Pract. 2006;56(532):848-856.

31. Litwin AH, Smith BD, Drainoni ML, et al. Primary care-based interventions are associated with increases in hepatitis $C$ virus testing for patients at risk. Dig Liver Dis. 2012;44(6):497-503.

32. Richter C, Ter Beest G, Gisolf EH, et al. Screening for chronic hepatitis $B$ and $C$ in migrants from Afghanistan, Iran, Iraq, the former Soviet Republics, and Vietnam in the Arnhem region, The Netherlands. Epidemiol Infect. 2014;142(10):2140-2146.

33. Menger $H$, Neve G. 'Vietnam tussen de tulpen' Screening op hepatitis B van Vietnamese inwoners van Noord-Holland. Infectieziekten Bulletin. 2013;24(2):45-47.

34. Grintjes K, Dofferhoff ASM, Stelma F, et al. Hepatitis C-opsporing onder migranten in Nijmegen (HECOM). Tijdschrift voor Infectieziekten. 2014;9(5):126-133.

35. Niessen W, Benne R, van Zeijl J, van der Have J, Broer J. Is het schriftelijk oproepen van immigranten voor hepatitis B-onderzoek effectief? Infectieziekten Bulletin. 2013;24(4):107-111.

36. van der Veen YJJ, van Empelen $P$, de Zwart O, Visser H, Mackenbach JP, Richardus JH. Cultural tailoring to promote hepatitis $B$ screening in Turkish Dutch: a randomized control study. Health Promot Int. 2013;29(4):692-704.

37. Galbraith JW, Franco RA, Donnelly JP, et al. Unrecognized chronic hepatitis C virus infection among baby boomers in the emergency department. Hepatology. 2015;61(3):776-782.

38. Zuure FR, Davidovich U, Coutinho RA, et al. Using mass media and the Internet as tools to diagnose hepatitis C infections in the general population. Am J Prev Med. 2011;40(3):345-352.

39. Zuure FR, Bouman J, Martens $M$, et al. Screening for hepatitis $B$ and $C$ in first-generation Egyptian migrants living in the Netherlands. Liver Int. 2013;33(5):727-738.

40. Marschall T, Kretzschmar M, Mangen MJ, Schalm S. High impact of migration on the prevalence of chronic hepatitis $B$ in the Netherlands. Eur J Gastroenterol Hepatol. 2008;20(12):1214-1225.

41. van Marrewijk CM, Velshuijzen IK, Conyn-van Spaendonck MAE, Kooy H, van den Hof S, Dorigo-Zetsma JW. Prevalence of hepatitis $B$ viral markers in the Dutch population: a population-based serosurveillance study (Pienter project). Prevalentie van hepatitis $B$ virale markers in de Nederlandse bevolking: een population-based seroprevalentie studie (Pienter project) 1999. http://www.rivm.nl/bibliotheek/ rapporten/243680001.html.

42. Orkin C, Flanagan S, Wallis E, et al. Incorporating HIV/hepatitis B virus/hepatitis $C$ virus combined testing into routine blood tests in nine UK Emergency Departments: the "Going Viral" campaign. HIV Med. 2016;17(3):222-230.

43. Hutton DW, Tan D, So SK, Brandeau ML. Cost-effectiveness of screening and vaccinating Asian and Pacific Islander adults for hepatitis B. Ann Intern Med. 2007;147(7):460-469.

44. Veldhuijzen IK, Toy M, Hahné SJ, et al. Screening and early treatment of migrants for chronic hepatitis B virus infection is costeffective. Gastroenterology. 2010;138(2):522-530.

45. Gezondheidsraad. Screening Risk Groups for Hepatitis B and C. The Hague: Health Council of the Netherlands; 2016.

46. Clark PJ, Muir AJ. Overcoming barriers to care for hepatitis C. $N$ Engl J Med. 2012;366(26):2436-2438.

47. Cruts AAN, Van Laar M, Buster M. Aantal en kenmerken van problematische opiatengebruikers in Nederland. Utrecht: Trimbos-instituut; 2013.

48. Van Laar M, Van Gageldonk A, Ketelaars T, Van Ooyen M, Cruts G, Croes E. Report to the EMCDDA by the Reitox National Focal Point. The Netherlands Drug Situation 2005. Utrecht: Trimbos-instituut; 2006. https://www.wodc.nl/binaries/1226-full-text_tcm28-68365.pdf. 